Clemson University

TigerPrints

$1-2015$

Professional Development and Teacher Change: The Missing Leadership Link

Brooke A. Whitworth

Jennifer L. Chiu

Follow this and additional works at: https://tigerprints.clemson.edu/teach_learn_pub 


\title{
Professional Development and Teacher Change: The Missing Leadership Link
}

\author{
Brooke A. Whitworth · Jennifer L. Chiu
}

(C) The Association for Science Teacher Education, USA 2014

\begin{abstract}
Professional development in science education aims to support teacher learning with the ultimate goal of improving student achievement. A multitude of factors influence teacher change and the effectiveness of professional development. This review of the literature explores these factors and identifies school and district science leaders as a critical factor missing from current professional development models. School and district leaders play a significant role in the planning and implementation of professional development, as well as providing ongoing leadership to support teacher change. Considering this role, school district leaders are not just a contextual factor, but rather an integral part of the process and should be integrated into and considered part of any professional development model in science education.
\end{abstract}

Keywords Professional development - Teacher change - Leadership · District leaders

\section{Introduction}

Professional development aims to improve teacher learning and practices, and ultimately students' learning, specifically in science (Fishman, Marx, Best, \& Tal, 2003; Loucks-Horsley, Stiles, Mundry, Love, \& Hewson, 2010). Professional

\footnotetext{
B. A. Whitworth $(\bowtie)$

Center for Science Teaching and Learning, Northern Arizona University, PO Box 5697, Flagstaff, AZ 86011, USA

e-mail: Brooke.Whitworth@nau.edu

J. L. Chiu

Curry School of Education, University of Virginia, 405 S. Emmet Street, Charlottesville, VA 22904, USA
} 
development in the USA is estimated to cost $\$ 1$ billion- $\$ 4$ billion per year (Wilson, 2013). Science teachers in the USA have access to a multitude of professional development opportunities including mentoring, national, state, and local conferences, content-specific courses, summer institutes, school-based opportunities provided by schools or districts, research experiences, and coaching (Pianta, 2011; Wilson, 2013). While teachers believe professional development can help them become more effective teachers and benefit their students (Luft \& Hewson, 2014; Whitehurst, 2002), not all professional development results in teacher change, and very few link to student outcomes (Yoon, Duncan, Lee, Scarloss, \& Shapley, 2007). Given the amount of resources being spent on professional development, it is critical to understand what factors contribute to teacher change and increases in student achievement in science education.

To illustrate a conceptual framework for studying the effects of professional development on teachers and students, Desimone (2009) suggests that effective professional development can result in teacher learning and changes in attitudes and beliefs, subsequently changing teacher practices. Ideally, change in practice leads to increased student achievement. Desimone's (2009) model sets this path within a context of teacher and student characteristics, curriculum, school leadership, and policy environment (Fig. 1).

Many studies exist on professional development and teacher change, documented by extensive reviews (Borko, 2004; Desimone, 2009). Several meta-analyses and syntheses of the research suggest a relationship between professional development and teacher change, and between teachers and student achievement (Darling-Hammond, 1999; Guskey \& Sparks, 1996; Hattie, 2008; Stronge, 2010; Wallace, 2009; Yoon et al., 2007). However, relatively few studies connect the role of leaders who plan and implement professional development to teacher change (Borko, 2004; Little \& Wong, 2007; Luft \& Hewson, 2014; Stein, Smith, \& Silver, 1999). The present work utilizes Desimone's (2009) model as a framework for reviewing literature on the characteristics of effective professional development and links to teacher change, as well as professional development and student achievement. We then review the literature on the factors influencing teacher change and identify school and

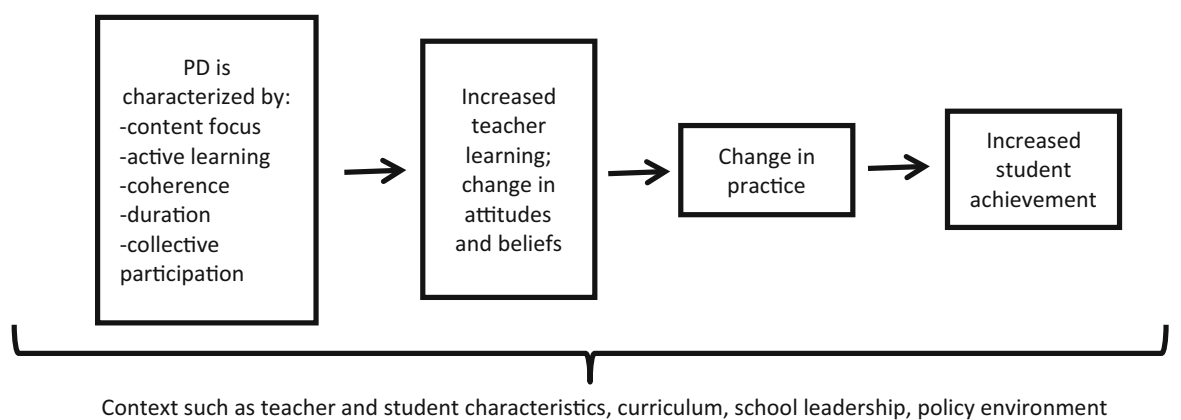

Fig. 1 Model for studying the effects of professional development on science teachers and students (modified from Desimone, 2009) 
district leaders as a critical component in science education rather than a contextual factor of professional development.

\section{Characteristics of Effective Professional Development and Teacher Change}

For the purposes of this review, we define teacher change as change in teacher beliefs, understandings, and/or practices. Researchers generally agree that professional development should include active learning, a strong content focus, be coherent and of a significant duration, and involve collective participation (Birman, Desimone, Porter, \& Garet, 2000; Desimone, 2009; Garet, Porter, Desimone, Birman, \& Yoon, 2001; Luft \& Hewson, 2014). These general characteristics are some of the design elements and conditions of professional development that are most successful in promoting teacher change and/or affecting student achievement across subjects (Borko, 2004; Garet et al., 2001; Knapp, 2003).

To support teacher growth, teachers should be actively engaged in their own learning (Desimone, 2009; Guskey, 1997, 1999; Sparks, 1994, 1995) and reflect upon their own understanding and practice (Heller, Daehler, Wong, Shinohara, \& Miratrix, 2012). Professional development can support active learning in a variety of ways, including: observing other teachers, practicing what has been learned and receiving feedback, reviewing and analyzing student work, leading and participating in discussions, applying their new knowledge to lesson plans, or participating in activities as students (Birman et al., 2000). Professional development programs that incorporate active learning strategies such as practice teaching, planning, presenting, and reviewing student work can contribute to teacher learning (Garet et al., 2001; Heller et al., 2012).

The content knowledge of teachers plays a vital role in both the quality of instruction and student performance (e.g., Darling-Hammond, 1999; Shulman, 1986). Professional development characterized by a content focus not only leads to increased teacher knowledge but also can lead to changes in teacher practices (Birman et al., 2000; Desimone, 2009; Desimone, Porter, Garet, Yoon, \& Birman, 2002; Garet et al., 2001; Kennedy, 1999). Furthermore, professional development lacking a strong content component has been found to be ineffective in changing teacher practices (Cohen \& Hill, 2000; Kennedy, 1998).

Coherence refers to how professional development can be integrated into a program of teacher learning (Birman et al., 2000). Professional development should be well aligned with the national, state, district, and school policies and standards (Desimone, 2009; Garet et al., 2001). Professional development activities should help teachers plan to implement changes in their classrooms (Ottoson, 1997) and help teachers identify and strategize about barriers they will encounter once back in their schools (Ottoson, 1997) through mentoring and coaching (Luft et al., 2011). Mentoring and coaching also supports teachers as they try to implement new practices from professional development programs (Grierson \& Woloshyn, 2013; Luft et al., 2011; Smith \& Ingersoll, 2004). Specifically, providing teachers with individualized feedback, tailored to their needs and classrooms, can support teachers to make substantial changes to their existing practices (Grierson \& Woloshyn, 2013). 
Duration concerns the number of hours of professional development and the amount of time over which it occurs (Desimone, 2009). Longer professional development spread out over time, like a full year or semester, tends to be characterized by more active learning, content focus, and coherence than shorter activities (Birman et al., 2000). Short, single workshops common to teacher professional development days have little follow-up and have little effect on teacher growth or understanding (Loucks-Horsley \& Matsumoto, 1999; Pianta, 2011; Spillane, 2002). Research demonstrates that professional development of a longer duration is more effective in changing teacher practices (Banilower, Heck, \& Weiss, 2007; Boyle, Lamprianou, \& Boyle, 2005; Cohen \& Hill, 2000; Gerard, Varma, Corliss, \& Linn, 2011).

Collective participation occurs when teachers from the same school, department, subject, or grade attend professional development together (Desimone, 2009). When teachers from similar areas attend professional development together, it is more effective (Porter, Garet, Desimone, Yoon, \& Birman, 2000) and enables conversations and discussions that increase teacher change (Birman et al., 2000; Borko, 2004; Loucks-Horsley \& Matsumoto, 1999). Other positive aspects of collective participation are the ability of teachers to discuss curricular changes as a group and to work toward developing their own professional learning community (Birman et al., 2000).

\section{Characteristics of Effective Professional Development in Science}

The National Science Education Standards (NSES; National Research Council [NRC], 1996) put forth guidelines for effective professional development specific to science. Some of the guidelines align with general characteristics, such as coherence and emphasis on content knowledge (NRC, 1996). However, some of the standards are unique to the practice of science teaching. For example, the NSES calls for professional development to help teachers develop content knowledge through inquiry-based methods and perspectives. Professional development should get teachers actively involved in investigating phenomena, interpreting results, and sense-making practices (e.g., Jeanpierre, Oberhauser, \& Freeman, 2005; Luft, 2001).

Effective professional development in science should not only help teachers develop content knowledge, but also help teachers integrate their knowledge of science, learning, pedagogy, and students and apply that to their practice (NSES, 1996). Thus, professional development programs in science education should help teachers develop and apply pedagogical content knowledge (e.g., Fishman, Marx, Best, \& Tal, 2003).

Guidelines for professional development in science also emphasize helping teachers become lifelong learners (NRC, 1996). Building from characteristics of active learning and duration, standards for science professional development include providing frequent opportunities for feedback, examination, and reflection upon practice (e.g., Roth et al., 2011). 


\section{Linking Professional Development to Student Achievement}

Teachers are considered the most important factor in student achievement (Carey, 2004; Haycock, 1998; Sanders \& Rivers, 1996); therefore, effective professional development should result in increased student achievement (Guskey, 1986, 2002; Loucks-Horsley \& Matsumoto, 1999). Although much research investigates the impact of professional development on teacher change, less research exists that explicitly links professional development to student outcomes (Desimone, 2009; Kennedy, 1998). Existing literature indicates that when characteristics of effective professional development are present, student achievement can be improved (Buczynski \& Hansen, 2010; Desimone, 2009; Johnson, Kahle, \& Fargo, 2007; Wallace, 2009; Yoon et al., 2007).

For example, in a systematic review, Yoon et al. (2007) identified 1,300 studies as having the potential to address the effectiveness of teachers' in-service professional development on student achievement in science, reading, and mathematics. Only nine studies met the standards for "evidence without reservation" in the What Works Clearinghouse standards, and all focused on elementary teachers. Results revealed that intense, sustained professional development was directly related to student achievement across subjects. Findings also highlight the lack of rigorous studies examining the relationship between teacher change and student outcomes, particularly at the secondary level.

Wallace (2009) examined the effect of professional development on teacher practices and student achievement in mathematics and reading. Results indicated that professional development had moderate effects on teacher practice and small, but sometimes significant effects on student achievement. Wallace (2009) concluded that despite differences in samples, academic subjects, and types of assessment, the effects of professional development on teacher practice and student achievement were similar and consistent across analyses of six large state and national databases.

Effective professional development once implemented in the classroom may also narrow the achievement gap (Johnson et al., 2007; Lee, Deaktor, Enders, \& Lambert, 2008). For example, Lee et al. (2008) examined the impact of a 3-year professional development program on science achievement of culturally and linguistically diverse elementary students. Results demonstrated significant increases each year on all measures of student achievement. The consistent positive results indicated professional development increased student achievement, especially for low-achieving, low socioeconomic status, and ELL students.

Despite the positive effects seen in these studies, professional development may not always result in student learning (Duffy et al., 1986; Saxe, Gearhart, \& Nasir, 2001). Teachers may need time to transfer what they learn in professional development into practice. For example, Johnson et al. (2007) investigated the relationship between characteristics of professional development and student achievement in science with a 3-year longitudinal study. Analysis showed a significant relationship between student achievement in science and teacher participation in whole-school, sustained, collaborative professional development. Interestingly, positive effects were found in years two and three, but not in year one. 
Results suggest the delay may be due in part to the amount of time it took for teachers to integrate what they learned into their practice.

\section{Factors Influencing Teacher Change}

Teachers come to professional development opportunities with different backgrounds, confidence, and motivation. The schools and districts they work within have different policies, approaches, and visions. The size, resources, working conditions, and leadership styles of administrators are also unique. This section concentrates on contextual professional development factors as defined by Desimone (2009) and whether or not they influence teacher change and ultimately increase student achievement.

Teacher experience (years in the classroom) is a critical factor to consider in professional development and teacher change (Smith, Hofer, Gillespie, Solomon, \& Rowe, 2003). Teachers who are in the beginning of their career or who have lower levels of formal education participate in more professional development than their counterparts (Livneh \& Livneh, 1999). For example, Luft (2001) compared the beliefs and practices of beginning and experienced science teachers after participation in an inquiry-based professional development. Results indicated that the beginning teacher group changed their beliefs more than their practices and the experienced teacher group changed their practices more than their beliefs (Luft, 2001). Similarly, teacher experience can impact the type of professional development teachers choose to attend. For example, beginning teachers tend to choose professional development focused on classroom management and new pedagogy, while experienced teachers tend to seek professional development to advance content and pedagogical knowledge (Lewis et al., 1999). Thus, professional development may need to tailor activities to the various levels of teacher experience (Smith \& Ingersoll, 2004).

Teachers may have a variety of motivations for attending professional development including: salary increase, licensure reaccreditation, career mobility, and gaining new skills or knowledge (Stout, 1996). In one survey study of K-12 educators, two motivational factors, high internal motivation to learn (gaining new skills or knowledge) and high external motivation to learn (career mobility, licensure reaccreditation), predicted teachers' participation in professional development (Livneh \& Livneh, 1999). Additionally, teachers who exhibit a strong motivation to attend professional development are more likely to change following participation (Smith et al., 2003).

Another contextual factor related to teacher change is self-efficacy. Self-efficacy is defined as "beliefs in one's capabilities to organize and execute the courses of action required to manage prospective situations" (Bandura, 1995, p. 2). Selfefficacy is related to the individual factors of teachers, including whether a teacher is beginning or more experienced (Ross, 1994). More experienced teachers tend to have more stable self-efficacy, while beginning teachers are still developing their self-efficacy (Ross, 1994). Teachers with stronger self-efficacy are more likely to change their practices as a result of attending professional development, regardless 
of experience (Guskey, 1988; Smylie, 1988). Higher levels of teacher self-efficacy have also been related to high levels of student achievement (Goddard, Hoy, \& Hoy, 2000; Tschannen-Moran, Hoy, \& Hoy, 1998). Teachers can increase their selfefficacy by implementing new practices (Stein \& Wang, 1988), and self-efficacy may increase more when teachers see these new practices work (Ross, 1998). Professional development of sufficient duration can also help teachers with low selfefficacy to increase their self-efficacy (Roberts, Henson, Tharp, \& Moreno, 2000). For example, researchers found that professional development to help science teachers develop content knowledge led to increased self-efficacy and increased use of inquiry-based instruction in the classroom (Lakshmanan, Heath, Perlmutter, \& Elder, 2011).

School culture also influences teacher retention and classroom practices (Bianchini \& Cavazos, 2007; McGinnis, Parker, \& Graeber, 2004). For example, in an interpretive case study of eight teachers, school culture was found to be a key factor in influencing whether or not beginning mathematics and science teachers grew professionally and continued in the profession (McGinnis et al., 2004). In schools where there is a school culture of collegiality, the effectiveness of professional development in changing mathematics and science teacher practices increases (Bianchini \& Cavazos, 2007; McGinnis et al., 2004). This collegiality creates an environment where professional communities can develop and teachers are able to learn and work together as they apply changes to their practices (Grossman, Wineburg, \& Woolworth, 2000). Furthermore, the more collaboration there is within a school, the more teachers are committed to teaching, which may result in teachers being more open to new practices and knowledge (Rosenholtz, 1986).

Working conditions, like full time versus part time, salary, and benefit levels, can have an effect on teacher turnover (Ingersoll, 2001). Teachers who are "dissatisfied" or who have low salaries, little support from administration, issues with student behavior, or have little input into decision making are more likely to leave teaching or move to different schools (Fullan, 2007). Amount of prep time, benefits, and school situation can also limit the amount and permanence of teacher change (Smith et al., 2003).

\section{Ongoing Leadership for Teacher Change}

Beyond the contextual factors of teacher experience, motivation, self-efficacy, school culture, and working conditions, district leadership plays a significant role in teacher change (Leithwood, Seashore-Louis, Anderson, \& Wahlstrom, 2004; Marsh, 2002). District leadership encompasses the roles of staff developers, subject-area supervisors, district coordinators, mentor teachers, school-board members, directors, and community members, but is most often focused on the role of the superintendent (Murphy \& Hallinger, 1988; Petersen, 1999; Waters \& Marzano, 2007). Ogawa and Bossert (1995) assert educational leadership is characteristic of the organization as a whole and that everyone in these roles helps shape the 
leadership a district provides. District leaders set the direction for reform efforts and professional development (Leithwood et al., 2004; Marsh, 2002).

School leadership plays a critical role in improving science teachers' instruction through professional development and other administrative practices (Banilower et al., 2007; Corcoran, Fuhrman, \& Belcher, 2001). School leadership has been shown to have a significant impact on student achievement (Marzano, Waters, \& McNulty, 2005). Research suggests that school and district leadership may be second only to the teaching occurring in the classroom as having the most impact on student achievement (Leithwood et al., 2004). Leadership can prepare teachers for change by creating environments that allow for natural change in teachers when they see if and how new practices help students (Sparks, 1995). Likewise, schools without effective leadership or with a high principal turnover rate can result in a negative effect on teacher programs (Bollough, Kauchak, Crow, Hobbs, \& Stoke, 1997).

The school district is a major provider of teachers' professional development (Spillane, 2002). According to Pianta (2011), districts spend thousands of dollars per teacher per year on professional development. Unfortunately, district-offered professional development often does not incorporate characteristics of effective professional development and is typically delivered in the form of short in-service workshops with little or no follow-up (Loucks-Horsley \& Matsumoto, 1999; Pianta, 2011; Spillane, 2002). These "one shot" workshops often lack coherence (Spillane, 2002), and instead of being content focused, they address administrative, management, or discipline issues and, as a result, are often ineffective (Desimone, Smith, \& Phillips, 2007; Pianta, 2011).

Conversely, districts can have a strong influence on teaching and learning through high-quality professional development (Desimone et al., 2002; Firestone, Mangin, Martinez, \& Plovsky, 2005). Alignment of professional development with standards, development of continuous improvement efforts, and teacher involvement in the planning of professional development are successful effective professional development practices for districts (Desimone et al., 2002). Additionally, action-based research of three districts' implementation of professional development indicated coherent, content-focused professional development planned by the district can have a positive effect on teaching and learning (Firestone et al., 2005).

District leaders not only support teachers' instructional practices, they also have a role in supporting student achievement. For example, Murphy and Hallinger (1988) studied the district leadership of 12 high-performing school districts in California. The authors found that successful districts in terms of student performance on standardized tests had leaders that made decisions based on systematic analysis and application of data, superintendents who were actively involved in the development and implementation of curricular reforms, and structured district control with school autonomy. In an extensive meta-analysis of 30 years of research, Marzano et al. (2005) explored the relationship between district leadership and student achievement and found an average correlation of .25 from 69 empirical studies between general leadership and student achievement. Effective leadership characteristics that directly correlated with student achievement included: monitoring and evaluating 
school curriculum, instruction, and assessment practices; creating a collaborative culture; working from a well-defined set of ideals and beliefs; maintaining knowledge of and involved with the curriculum, instruction, and assessment; and forming concrete goals (Marzano et al., 2005).

Taken together, these studies describe the characteristics of effective district leadership and indicate key practices of effective leadership that include focusing on learning, building professional communities, acting strategically and sharing leadership, and creating coherence (Copland \& Knapp, 2006). While there is extensive research in the area of effective district leadership, all studies agree there is not a "recipe" or one set of tasks a leader should follow to be effective (e.g., Murphy \& Hallinger, 1988). However, it is clear effective leadership includes collaboration and working together to support teacher instruction and student learning (Leithwood et al., 2004). Furthermore, research indicates student learning suffers when central office administrators do not provide needed support for teachers (Honig \& Copland, 2008).

\section{Implications}

Based on the research reviewed, there is support for and value in Desimone's (2009) model (Fig. 1). However, the leadership within the school and district plays a more prominent role than merely a contextual factor as school districts are the primary providers of professional development and ongoing support for teacher learning, which can ultimately affect student achievement (Birman et al., 2007; Leithwood et al., 2004; Pianta, 2011; Spillane, 2002). Thus, school and district leadership should be emphasized more in the model than originally proposed by Desimone (2009). Based upon this evidence, school and district leaders should be considered at the start of the path toward student achievement rather than as part of the context (Fig. 2).

While schools and districts are not the only facilitators of professional development for teachers, they are the main provider (Birman et al., 2007; Pianta,

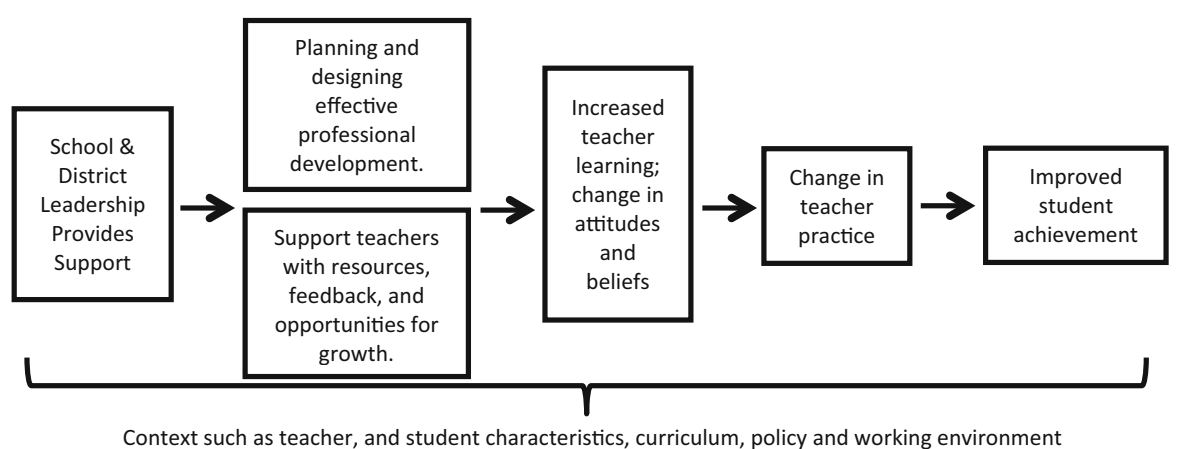

Fig. 2 Proposed model for investigating the links between professional development and student achievement 
2011; Spillane, 2002). Therefore, it is critical to understand school and district leaders' views of professional development, their practices, and the factors that influence school and district leadership in choosing and designing professional development. Understanding these factors can provide insight into what types of professional development districts choose for teachers to experience. Furthermore, understanding how district leaders choose and implement professional development (either formal or ongoing) may also illuminate areas in which school and district leaders need professional development themselves. School and district leaders who benefit from consistent professional development themselves may be more proactive in facilitating effective professional development for their district.

\section{Subject-Area Coordinators}

The review of the literature also reveals a gap in the research around the role of subject-area coordinators. Subject-area leaders, such as district science coordinators, are individuals who are intimately involved in the administration and execution of leadership activities associated with curriculum and instruction (Spillane, Camburn, \& Stitziel, 2007). Science coordinators are often part of district administration and are involved in the decisions that affect the instructional practices of teachers, such as administering district-wide professional development or providing day-to-day support for teachers in their subjects. However, there is very little research on this population (Honig, 2006), despite their central role in the implementation and crafting of reforms in schools (Honig \& Hatch, 2004).

For example, a few studies have investigated the role of science coordinators (Aoki, 2003; Lee, Leary, Sellers, \& Recker, 2014; Perrine, 1984; Roden, 2003). Research suggests that science coordinators have an influence over how teachers choose and use instructional resources (Knapp \& Plecki, 2001). Furthermore, research suggests the experience and expertise of science coordinators may be a crucial factor in the support of first-year teachers in the classroom (Roden, 2003). However, research also suggests that teachers and administrators have varying opinions about the role and duties of science coordinators (Madrazo \& Hounshell, 1987; Madrazo \& Motz, 1982) and actual practices of science coordinators vary widely from district to district (Lee et al., 2014). Thus, more research is needed to explore the role of subject-area coordinators and how these leaders can effectively provide support for teacher change (e.g., President's Council of Advisors on Science and Technology [PCAST], 2010; Perrine, 1984) as well as how professional development can be designed to include science coordinators.

\section{Implications for Designing Professional Development}

Based on this literature review, effective professional development programs should include and provide tailored support for district leadership. Many professional development programs can be decontextualized and conducted outside of schools for implementation in schools (Putnam \& Borko, 2000). Without explicit involvement and support from leadership, teachers can be left on their own to enact and maintain any changes in practice. Involving school leaders in science 
education professional development efforts can support teacher change by helping teachers develop professional communities, connecting teachers with resources, and encouraging and supporting changes in practice (Halverson, Feinstein, \& Meshoulam, 2011). Involving leadership in professional development can also help leaders understand the value of the program, the resources needed for teachers to enact the change in practice, and thus give leaders opportunities to plan and reflect upon how to support the intended changes in their particular contexts (Spillane, Halverson, \& Diamond, 2001). Unfortunately, very few examples exist of professional development programs in science that explicitly involve leaders. We draw upon the Technology-Enhanced Learning in Science (TELS) Center, the Collaborating and Networking Learning Environment and Database (CANLEAD) project, and the Virginia Initiative for Science Teaching and Achievement (VISTA) projects as examples of how leadership can be integrated into professional development efforts.

The TELS project provided principals with specifically designed professional development as a part of a computer-based inquiry science professional development program that included fifteen school districts in five states (Gerard, Bowyer, \& Linn, 2008). Principals from the participating schools engaged in a tailored workshop that included hands-on experience with the inquiry curricula, analysis of student data from the units, discussions with teachers and other principles, and reflection on leadership and successful implementation of the inquiry-oriented curricula. Principals reported that understanding the curricula and content of the program helped them recognize how to best support their teachers at their schools and enhance their leadership ability (Gerard et al., 2008).

The CANLEAD project provides an example of how professional development can be designed to help leaders support teachers in school-specific contexts (Dexter, 2014). CANLEAD focuses on supporting technology-enhanced instruction in mathematics and science by providing professional development to school leadership teams consisting of principals, district technology and/or subject coordinators, and mathematics and science department chairs. The professional development program focuses on discussing leadership best practices, technologies with specific affordances for mathematics and science instruction, and ways to utilize technologies to promote teacher learning. During the initial summer institute, individual school leadership teams collaboratively decide on which resources to implement and use with their science and mathematics teachers and begin planning to support integrating the recommended technologies in their schools. The project team also provides monthly and as-needed assistance to the leaders throughout the school year. Results suggest that the participation of school leaders improved communication between school leaders and teachers and helped align organizational and teacher learning goals (Jones, 2014).

The VISTA project aims to build an infrastructure to support sustained, intensive science teacher professional development to increase student performance (Bell, Konold, Maeng, \& Heinecke, 2012). As part of VISTA, the Elementary Science Institute (ESI) specifically includes school and district leaders in the professional development. The VISTA ESI provides professional development to school teams of teachers focused on reforms-based practices (e.g., problem-based learning, 
inquiry, and nature of science). During the ESI, principals from their schools and district science coordinators from their districts attend for 1 day and are given the opportunity to experience some of the professional development, interact with their teachers, and learn about the type of support teachers will need when they return to the classroom. District science coordinators are asked to attend a second day where they have the opportunity to work with teachers as they are developing problembased learning units back to their schools. Similar to the TELS findings, preliminary results indicate principals increased their understanding of how to support science teachers as a result of attendance (Bell et al., 2012). Teachers also rated their principals higher at being effective in supporting science instruction following the professional development.

The New Science Coordinator Academy (NSCA) is another component of the VISTA project designed to provide professional development to district science coordinators in the first 5 years of their career. The NSCA focuses on creating opportunities for science coordinators to learn about best practices in science education, develop district strategic plans, discuss and increase leadership skills, and create opportunities for networking and community building. This is the only opportunity, to our knowledge, that is designed specifically for district science coordinators. Results indicate science coordinators' understandings about pedagogy and job responsibilities changed following their participation; however, their practices were not fully aligned with their understandings (Whitworth, 2014). Results also indicate that barriers such as perceived lack of authority within districts may hinder coordinators' ability to fully implement needed changes, highlighting the need to include other district stakeholders in professional development efforts.

\section{Conclusion}

High-quality professional development is a crucial component to improving science education (Guskey, 1986, 2002; Wilson, 2013). The research reviewed here reveals that under the right conditions professional development may help teachers be more effective and may also result in gains in student achievement (Yoon et al., 2007). Yet, many factors including teacher motivation, school culture, and working conditions mediate the effects of professional development. This review also highlights the critical role of district leaders in supporting teacher change in beliefs, understandings, and/or practices. However, existing models of professional development fail to consider the integral role of school and district leadership (e.g., Desimone, 2009; Loucks-Horsley \& Matsumoto, 1999). In particular, more research needs to explore the role of science coordinators in providing domainspecific professional development (Luft \& Hewson, 2014; PCAST, 2010) as well as study how to include leadership in professional development efforts. It is critical for us to consider the role of school and district leaders in facilitating teacher change if we want to have a more complete picture of the role of professional development in facilitating teacher and ultimately student learning in science. 


\section{References}

Aoki, J. M. (2003). The perceptions of inquiry held by greater Houston area science supervisors (Doctoral dissertation). Houston, TX: University of Houston.

Bandura, A. (Ed.). (1995). Self-efficacy in changing societies. Cambridge: Cambridge University Press.

Banilower, E. R., Heck, D. J., \& Weiss, I. R. (2007). Can professional development make the vision of the standards a reality? The impact of the National Science Foundation's local systemic change through teacher enhancement initiative. Journal of Research on Science Teaching, 44, 375-395.

Bell, R. L., Konold, T., Maeng, J. L., \& Heinecke, W. F. (2012). VISTA research and evaluation annual report: Year 2. Unpublished report for George Mason University.

Bianchini, J. A., \& Cavazos, L. M. (2007). Learning from students, inquiry into practice, and participation in professional communities: Beginning teachers' uneven progress toward equitable science teaching. Journal of Research in Science Teaching, 44, 586-612.

Birman, B. S., Desimone, L., Porter, A. C., \& Garet, M. S. (2000). Designing professional development that works. Educational Leadership, 57(8), 28-33.

Birman, B., Le Floch, K. C., Klekotka, A., Ludwig, M., Taylor, J., Walters, K., .. Yoon, K. (2007). State and local implementation of the No Child Left Behind Act: Vol. 2. Teacher quality under NCLB: Interim report. Washington, DC: U.S. Department of Education; Office of Planning, Evaluation and Policy Development; Policy and Program Studies Service.

Bollough, R. V., Kauchak, D., Crow, N., Hobbs, S., \& Stoke, D. (1997). Professional development schools: Catalysts for teacher and school change. Teaching and Teacher Education, 13, 153-169.

Borko, H. (2004). Professional development and teacher learning: Mapping the terrain. Educational Researcher, 33(8), 3-15.

Boyle, B., Lamprianou, I., \& Boyle, T. (2005). A longitudinal study of teacher change: What makes professional development effective? Report of the second year of the study. School Effectiveness and School Improvement, 16, 1-27.

Buczynski, S., \& Hansen, C. B. (2010). Impact of professional development on teacher practice: Uncovering connections. Teaching and Teacher Education, 26, 599-607.

Carey, K. (2004). The real value of teachers: Using new information about teacher effectiveness to close the achievement gap. Thinking $K-16,8(1), 3-42$.

Cohen, D. K., \& Hill, H. C. (2000). Instructional policy and classroom performance: The mathematics reform in California. Teachers College Record, 102, 294-343.

Copland, M. A., \& Knapp, M. S. (2006). Connecting leadership with learning: A framework for reflection, planning and action. Alexandria, VA: Association for Supervision and Curriculum Development.

Corcoran, T., Fuhrman, S. H., \& Belcher, C. L. (2001). The district role in instructional improvement. The Phi Delta Kappan, 83, 78-84.

Darling-Hammond, L. (1999). Teacher quality and student achievement: A review of state policy evidence. Seattle, WA: Center for the Study of Teaching and Policy, University of Washington.

Desimone, L. M. (2009). Improving impact studies of teachers' professional development: Toward better conceptualizations and measures. Educational Researcher, 38(3), 181-199.

Desimone, L. M., Porter, A. C., Garet, M. S., Yoon, K. S., \& Birman, B. F. (2002). Effects of professional development on teachers' instruction: Results from a three-year longitudinal study. Educational Evaluation and Policy Analysis, 24, 81-112.

Desimone, L. M., Smith, T. M., \& Phillips, K. J. R. (2007). Does policy influence mathematics and science teachers' participation in professional development? Teachers College Record, 109, 1086-1122.

Dexter, S. (2014). Collaboration and networking learning environment and database. Retrieved from http://canlead.net/

Duffy, G. G., Roehler, L. R., Meloth, M. S., Vavrus, L. G., Book, C., Putnam, J., \& Wesselman, R. (1986). The relationship between explicit verbal explanations during reading skill instruction and student awareness and achievement: A study of reading teacher effects. Reading Research Quarterly, 21, 237-252.

Firestone, W. A., Mangin, M. M., Martinez, M. C., \& Plovsky, T. (2005). Leading coherent professional development: A comparison of three districts. Educational Administration Quarterly, 41, 413-448.

Fishman, B. J., Marx, R. W., Best, S., \& Tal, R. T. (2003). Linking teacher and student learning to improve professional development in systemic reform. Teaching and Teacher Education, 19, 643-658. 
Fullan, M. (2007). Change the terms for teacher learning. National Staff Development Council, 28(3), $35-36$.

Garet, M. S., Porter, A. C., Desimone, L., Birman, B., \& Yoon, K. S. (2001). What makes professional development effective? Results from a national sample of teachers. American Educational Research Journal, 38, 915-945.

Gerard, L. F., Bowyer, J. B., \& Linn, M. C. (2008). Principal leadership for technology-enhanced learning in science. Journal of Science Education and Technology, 17(1), 1-18.

Gerard, L. F., Varma, K., Corliss, S. B., \& Linn, M. C. (2011). Professional development for technologyenhanced inquiry science. Review of Educational Research, 81, 408-448.

Goddard, R. D., Hoy, W. K., \& Hoy, A. W. (2000). Collective teacher efficacy: Its meaning, measure, and impact on student achievement. American Educational Research Journal, 37, 479-507.

Grierson, A. L., \& Woloshyn, V. E. (2013). Walking the talk: Supporting teachers' growth with differentiated professional learning. Professional Development in Education, 39, 401-419.

Grossman, P., Wineburg, S., \& Woolworth, S. (2000). What makes teacher community different from a gathering of teachers? (Occasional paper). Washington, DC: Center for the Study of Teaching and Policy and Center on English Learning and Achievement.

Guskey, T. R. (1986). Staff development and the process of teacher change. Educational Researcher, 15(5), 5-12.

Guskey, T. R. (1988). Teacher efficacy, self-concept, and attitudes toward the implementation of instructional innovation. Teaching and Teacher Education, 4, 63-69.

Guskey, T. R. (1997). Research needs to link professional development and student learning. Journal of Staff Development, 18(2), 36-40.

Guskey, T. R. (1999). Moving from means to ends. Journal of Staff Development, 20(1), 48.

Guskey, T. R. (2002). Professional development and teacher change. Teachers and Teaching: Theory and practice, 8, 381-391.

Guskey, T. R., \& Sparks, D. (1996). Exploring the relationship between staff development and improvements in student learning. Journal of Staff Development, 17(4), 34-38.

Halverson, R., Feinstein, N., \& Meshoulam, D. (2011). School leadership for science education. In G. E. DeBoer (Ed.), The role of public policy in K-12 science education (pp. 397-430). Charlotte, NC: Information Age.

Hattie, J. (2008). Visible learning: A synthesis of over 800 meta-analyses relating to achievement. New York, NY: Routledge.

Haycock, K. (1998). Good teaching matters...a lot. Thinking K-16, 3(2), 3-14.

Heller, J. I., Daehler, K. R., Wong, N., Shinohara, M., \& Miratrix, L. W. (2012). Differential effects of three professional development models on teacher knowledge and student achievement in elementary science. Journal of Research in Science Teaching, 49, 333-362.

Honig, M. I. (2006). Street-level bureaucracy revisited: Frontline district central-office administrators as boundary spanners in education policy implementation. Educational Evaluation and Policy Analysis, 28, 357-383.

Honig, M. I., \& Copland, M. A. (2008). Reinventing district central offices to expand student learning (Issue brief). Center for Comprehensive School Reform and Improvement.

Honig, M. I., \& Hatch, T. C. (2004). Crafting coherence: How schools strategically manage multiple, external demands. Educational Researcher, 33(8), 16-30.

Ingersoll, R. M. (2001). Teacher turnover and teacher shortages: An organizational analysis. American educational research journal, 38, 499-534.

Jeanpierre, B., Oberhauser, K., \& Freeman, C. (2005). Characteristics of professional development that effect change in secondary science teacher's classroom practices. Journal of Research in Science Teaching, 42, 668-690.

Johnson, C. C., Kahle, J. B., \& Fargo, J. D. (2007). A study of the effect of sustained, whole-school professional development on student achievement in science. Journal of Research in Science Teaching, 44, 775-786. doi:10.1002/tea.20149

Jones, M. (2014). Supporting science teacher learning of technology integration through new models and tools (Doctoral dissertation). Charlottesville, VA: University of Virginia.

Kennedy, M. M. (1998). Form and substance in in-service teacher education (Research monograph no. 1). Arlington, VA: National Science Foundation.

Kennedy, M. M. (1999). Form and substance in mathematics and science professional development. Madison, WI: University of Wisconsin at Madison, National Institute for Science Education. 
Knapp, M. (2003). Professional development as a policy pathway. Review of Research in Education, 27, $109-157$.

Knapp, M. S., \& Plecki, M. L. (2001). Investing in the renewal of urban science teaching. Journal of Research in Science Teaching, 38, 1089-1100.

Lakshmanan, A., Heath, B. P., Perlmutter, A., \& Elder, M. (2011). The impact of science content and professional learning communities on science teaching efficacy and standards-based instruction. Journal of Research in Science Teaching, 48, 534-551.

Lee, O., Deaktor, R., Enders, C., \& Lambert, J. (2008). Impact of a multiyear professional development intervention on science achievement of culturally and linguistically diverse elementary students. Journal of Research in Science Teaching, 45, 726-747. doi:10.1002/tea.20231

Lee, V. R., Leary, H. M., Sellers, L., \& Recker, M. (2014). The role of school district science coordinators in the district-wide appropriation of an online resource discovery and sharing tool for teachers. Journal of Science Education and Technology, 23, 309-323.

Leithwood, K., Seashore-Louis, K., Anderson, S., \& Wahlstrom, K. (2004). How leadership influences student learning. Minneapolis, MN: University of Minnesota, Center for Applied Research and Educational Improvement.

Lewis, L., Parsad, B., Carey, N., Bartfai, N., Farris, E., \& Smerdon, B. (1999). Teacher quality: A report on the preparation and qualifications of public school teachers (NCES 1999-080). Washington, DC: National Center for Education Statistics, US Department of Education.

Little, J. W., \& Wong, N. (2007). Conceptualizing the contribution of facilitation to professional learning opportunity. Paper presented at the American Educational Research Association annual meeting, Chicago, IL.

Livneh, C., \& Livneh, H. (1999). Continuing professional education among educators: Predictions of participation in learning activities. Adult Education Quarterly, 49, 91-106.

Loucks-Horsley, S., \& Matsumoto, C. (1999). Research on professional development for teachers of mathematics and science: The state of the scene. School Science and Mathematics, 99, 258-271.

Loucks-Horsley, S., Stiles, K. E., Mundry, S., Love, N., \& Hewson, P. W. (2010). Designing professional development for teachers of science and mathematics (3rd ed.). Thousand Oaks, CA: Corwin Press.

Luft, J. A. (2001). Changing inquiry practices and beliefs: The impact of an inquiry-based professional development programme on beginning and experienced secondary science teachers. International Journal of Science Education, 23, 517-534.

Luft, J. A., Firestone, J. B., Wong, S. S., Ortega, I., Adams, K., \& Bang, E. (2011). Beginning secondary science teacher induction: A two-year mixed methods study. Journal of Research in Science Teaching, 48, 1199-1224.

Luft, J. A., \& Hewson, P. W. (2014). Research on teacher professional development programs in science. In S. K. Abell \& N. G. Lederman (Eds.), Handbook of research on science education (Vol. II). New York, NY: Routledge.

Madrazo, G. M., \& Hounshell, P. B. (1987). Science supervisor: Results of research in science supervision. Science Education, 71, 9-14.

Madrazo, G., \& Motz, L. (1982). Science supervisors—An endangered species? Science Teacher, 49(9), 42.

Marsh, J. A. (2002). How districts relate to states, schools, and communities. In A. Hightower, M. S. Knapp, J. A. Marsh, \& M. W. McLaughlin (Eds.), School districts and instructional renewal (pp. 25-40). New York: Teachers College Press.

Marzano, R. J., Waters, T., \& McNulty, B. A. (2005). School leadership that works: From research to results. Denver, CO: Mid-continent Research for Education and Learning.

McGinnis, J., Parker, R., \& Graeber, C. A. (2004). A cultural prospective of the induction of five reformminded beginning mathematics and science teachers. Journal of Research in Science Teaching, 41, 720-747.

Murphy, J., \& Hallinger, P. (1988). Characteristics of instructionally effective school districts. The Journal of Educational Research, 81, 175-181.

National Research Council. (1996). National science education standards. Washington, DC: National Academy Press.

Ogawa, R., \& Bossert, R. (1995). Leadership as an organizational quality. Educational Administration Quarterly, 31, 224-244.

Ottoson, J. M. (1997). After the applause: Exploring multiple influences on application following an adult education program. Adult Education Quarterly, 47, 92-107. 
Perrine, W. G. (1984). Teacher and supervisory perceptions of elementary science supervisors. Science Edcuation, 68, 3-9.

Petersen, G. J. (1999). Demonstrated actions of instructional leaders: An examination of five California superintendents. Educational Policy Analysis Archives, 7(18).

Pianta, R. C. (2011). Teaching children well: New evidence based approaches to teacher professional development and training. Center for American Progress, 11, 1-36.

Porter, A. C., Garet, M. S., Desimone, L. D., Yoon, K. S., \& Birman, B. F. (2000). Does professional development change teaching practice? Results from a three-year study: Executive summary. Washington, DC: US Department of Education, Office of the Undersecretary.

President's Council of Advisors on Science and Technology. (2010). Prepare and inspire: K-12 education in science, technology, engineering, and math (STEM) for America's future. Retrieved from http://www.whitehouse.gov/sites/default/files/microsites/ostp/pcast-stem-ed-final.pdf

Putnam, R., \& Borko, H. (2000). What do new views of knowledge and thinking have to say about research on teacher learning? Educational Researcher, 29(1), 4-15.

Roberts, J. K., Henson, R. K., Tharp, B. Z., \& Moreno, N. (2000). An examination of change in teacher self-efficacy beliefs in science education based on the duration of in-service activities. Paper presented at the annual meeting of the American Educational Research Association, Dallas, TX.

Roden, J. (2003). Bridging the gap: The role of the science coordinator in improving the induction and professional growth of newly qualified teachers. Journal of In-Service Education, 29, 201-220.

Rosenholtz, S. (1986). Educational reform strategies: Will they increase teacher commitment? American Journal of Education, 95, 543-562.

Ross, J. A. (1994). The impact of an in-service to promote cooperative learning on the stability of teacher efficacy. Teaching and Teacher Education, 10, 381-394.

Ross, J. A. (1998). Antecedents and consequences of teacher efficacy. In J. Brophy (Ed.), Advances in research on teaching (Vol. 7, pp. 49-74). Greenwich, CT: JAI.

Roth, K., Garnier, H., Chen, C., Lemmens, M., Schwille, K., \& Wickler, N. (2011). Videobased lesson analysis: Effective science PD for teacher and student learning. Journal of Research in Science Teaching, 48, 117-148.

Sanders, W. L., \& Rivers, J. C. (1996). Cumulative and residual effects of teachers on future student academic achievement. Knoxville: University of Tennessee.

Saxe, G. B., Gearhart, M., \& Nasir, N. S. (2001). Enhancing students' understanding of mathematics: A study of three contrasting approaches to professional support. Journal of Mathematics Teacher Education, 4, 55-79.

Shulman, L. S. (1986). Those who understand: Knowledge growth in teaching. Educational Researcher, 15(2), 4-14.

Smith, C., Hofer, J., Gillespie, M., Solomon, M., \& Rowe, K. (2003). How teachers change: A study of professional development in adult education (NCSALL Rep. No. 25). Boston: National Center for the Study of Adult Learning and Literacy.

Smith, T., \& Ingersoll, R. (2004). What are the effects of induction and mentoring on beginning teacher turnover? American Educational Research Journal, 41, 681-714.

Smylie, M. A. (1988). The enhancement function of staff development: Organizational and psychological antecedents to individual teacher change. American Educational Research Journal, 25, 1-30.

Sparks, D. (1994). A paradigm shift in staff development. Journal of Staff Development, 15(4), $26-29$.

Sparks, D. (1995). Focusing staff development on improving student learning. In G. Cawelti (Ed.), Handbook of research on improving student achievement (pp. 163-169). Arlington, VA: Educational Research Service.

Spillane, J. P. (2002). Local theories of teacher change: The pedagogy of district policies and programs. Teachers College Record, 104, 377-420.

Spillane, J. P., Camburn, E. M., \& Stitziel, P. A. (2007). Taking a distributed perspective to the school principal's workday. Leadership and Policy in Schools, 6, 103-125.

Spillane, J. P., Halverson, R., \& Diamond, J. B. (2001). Investigating school leadership: A distributed practice. Educational Researcher, 30(3), 23-28.

Stein, M. K., Smith, M. S., \& Silver, E. A. (1999). The development of professional developers: Learning to assist teachers in new settings in new ways. Harvard Educational Review, 69, 237-269.

Stein, M. K., \& Wang, M. C. (1988). Teacher development and school improvement: The process of teacher change. Teaching and Teacher Education, 4, 171-187.

Stout, R. T. (1996). Staff development policy: Fuzzy choices in an imperfect market. Education Policy Analysis Archives, 4(2). Retrieved from http://epaa.asu.edu/ojs/article/view/625/747 
Stronge, J. H. (2010). Effective teachers = student achievement: What the research says. Larchmont, NY: Eye on Education.

Tschannen-Moran, M., Hoy, A. W., \& Hoy, W. K. (1998). Teacher efficacy: Its meaning and measure. Review of Educational Research, 68, 202-248.

Wallace, M. R. (2009). Making sense of the links: Professional development, teacher practices, and student achievement. Teachers College Record, 111, 573-596.

Waters, J. T., \& Marzano, R. J. (2007). School district leadership that works: The effect of superintendent leadership on student achievement. ERS Spectrum, 25(2), 1-12.

Whitehurst, G. (2002). Research on teacher preparation and professional development. Speech given at the White House conference on preparing quality teachers. Retrieved from http://www.stcloudstate. edu/tpi/initiative/documents/assessment/Scientifically\%20Based\%20Reserach\%20on\%20Teacher\% 20Quality.pdf

Whitworth, B. A. (2014). Exploring the critical role of a district science coordinator (Doctoral dissertation). Charlottesville, VA: University of Virginia.

Wilson, S. M. (2013). Professional development for science teachers. Science, 340, 310-313.

Yoon, K. S., Duncan, T., Lee, S. W.-Y., Scarloss, B., \& Shapley, K. (2007). Reviewing the evidence on how teacher professional development affects student achievement (Issues and Answers Report, REL 2007-No. 033). Washington, DC: US Department of Education, Institute of Education Sciences, National Center for Education Evaluation and Regional Assistance, Regional Educational Laboratory Southwest. 